\title{
Periphery formation and economic-social conflict
}

\author{
Botond Sinóros-Szabó - Béla Baranyi \\ University of Debrecen Centre for Agricultural and Applied Economic Sciences, Debrecen
}

drsinoros@hotmail.com

$S U M M A R Y$

\begin{abstract}
The timeliness, significance and importance of the study is sensitively shown by the fact that a large part of the Tisza region is slowly being moved to the periphery in the slowly modernising and changing economic and settlement spatial structure of the Great Plain. This situation is also deepened by the fact that the social and economic backlog increases in the majority of the region, as one third of the 33 most disadvantaged small regions in Hungary can be found here. This study basically contributes to the establishment of the development of the Tisza river's spatial environment and the development of new solutions.
\end{abstract}

Keywords: Tisza spatial environment, peripheries, social and economic backlog, development strategy

\section{ÖSSZEFOGLALÁS}

A tanulmány aktualitását, jelentőségét és fontosságát érzékenyen jelzi, hogy a Tisza-vidék nagy része a lassan modernizálódó és átalakuló alföldi gazdasági és települési térszerkezetben fokozatosan a perifériára kerül. A helyzetet súlyosbitja, hogy a társadalmi, gazdasági leszakadás a térség nagyobb részén egyre fokozódik, az ország 33 leghátrányosabb helyzetü kistérségének 1/3-a itt található. A tanulmány alapvetöen hozzájárul a Tisza folyó térkörnyezete fejlesztésének megalapozásához, új megoldások kialakitásához.

Kulcsszavak: Tiszatér környezet, perifériák, társadalmi-, gazdasági leszakadás, fejlesztési stratégia

The narrower-wider regions of the Tisa river have played - sometimes a quite determining - role, which was very changing considering its content, in the regional development of the entire Great Plains. Until the last third of the $19^{\text {th }}$ century, until river regulations, and until modern transport routes had been built up by its extended water system, floods, fairway, and the diversification and relatively developed settlements of its high bank reliefs, and crossing points - the Great Plains had a determining developmental and regional axis. Since then, a half century has passed and changed the general geographical and regional structure of the river and its environment in a crucial way. The Tisa as before such an important developmental axis of the Great Plains - essentially except for the still considerable nodes of crossings - lost its significance.

A great part of the Tisza-region in the slowly modernizing and changing economic and settlement axis of the Great Plains - partly except for its central and big cities - has gradually become marginalized. The carrying capacity of its agriculture has gradually decreased, the development of its network infrastructure has become lower than the otherwise low average of the Great Plains, the integrated „,cohabitation” - that has been formed in previous centuries of its settlements and the society of its settlements have mostly ceased with the river. Lately, as one of the serious consequences of the transition process in the narrower and wider environment of the Tisza, periphery formation has been amplifying, problems associated with disadvantage and multiple disadvantages have been accumulated, which became bases for serious economic and social problems and territorial conflicts at the same time.

The situation is getting worse, due to the fact that the social-economic breakaway is increasing in the greater part of the region, according to the statistical indicators, a significant part of the region along the
Tisza-river outer (along the border) and inner periphery (11 sub regions supported by the most disadvantageous complex programme, 4 most disadvantageous, and 11 disadvantageous (only 5 are not beneficiaries). The third sub region of the country (figure 3), which is in the worst situation out of the 33 that can be found here (Tisza strategy... 2010).

All in all, as the main characteristics of the underdeveloped, disadvantaged regions and declining sub regions mainly the following may be mentioned:

- significant developmental differences, regional inequalities;

- general social-economic underdevelopment;

- disadvantage and multiple disadvantage;

- acute, consistent and extremely high unemployment;

- deep, structural crisis, general deterioration of the industry (,brown field areas”, regions that lack industry, decline in the manufacturing industry etc.);

- the decline of agriculture (sales crisis), the shortcomings of the service sector;

- poor infrastructural supply, accessibility and isolation;

- long-term social crisis, the decline of the quality of life and living conditions (segregation, extreme poverty);

- deteriorating public safety (Baranyi, 2012).

The disadvantage is formed generally and in a specific situation based on the throng of causes and factors that are unfavourable, amplifying and built on each other. If the vast majority or all the factors determining the economicsocial development are unfavourable, there may be multiple disadvantages in regional and environmental context as well. Due to the complexity of disadvantageous or unfavourable indicators, multiple disadvantageous regions can be great geographical landscape areas, large regions (e.g. Great Plains, Tisza-region), planningstatistical developmental regions (e.g. Northern Great Plains), sub regions that can also be homogenous natural, 
geographical landscape areas (e.g. Bodrogköz, Sárrét, Bereg, Ormánság), or even so-called Central Bureau of Statistics sub regions, and more recently, complex, multi-purpose sub regional associations, and the districts that are under organisation. Nowadays, the most common and extended presence of the peripheral, declining areas, so-called depressed regions are generally experienced at the Southern and South-western corner of Transdanubia, and typically in the large region of the Great Plains, especially in the region of Northern Hungary including the 6 counties of the region of the Northern Great Plains and the region of Northern Hungary, particularly the areas along the Tisza river, especially in the Northern and Central Tisza region (Baranyi, 2004).

In connection with the latter facts, it could also be said that within Hungary, actually in the entire Eastern Hungarian region, especially the social-economic situation of North-eastern Hungary is considered to be a disadvantageous region in general, in its area there are multiple disadvantaged regions (Bordrogköz, Taktaköz, Central-Tisza region, Bihar, Sárrét, Szatmár, Bereg, Cserehát, etc.) in great numbers, and the external (along the border) peripheries - partly emerging from them - and also the transitional regions between the internal and external peripheries (e.g. the sub regions of Encs, Szikszó, Fehérgyarmat, Mátészalka, Sellye, Szigetvár). Simply put, it could be said that a significant part of the areas, which are imaginary areas located north of a line of Gyula-Szolnok-Balassagyarmat, contain one of the widespread crisis regions of the country. As long as, for instance, the Great Plains large region - within it North-eastern Hungary - is a disadvantaged peripheral region in the regional structure of the country, and compared to it, its widespread areas and settlements along the border are also struggling areas with further disadvantages, the „peripheries of the periphery” (Baranyi, 1999) (figure 1).

Figure 1: Micro-regional development based on 67/2007. (VI.28.) National Assembly (NA) decision

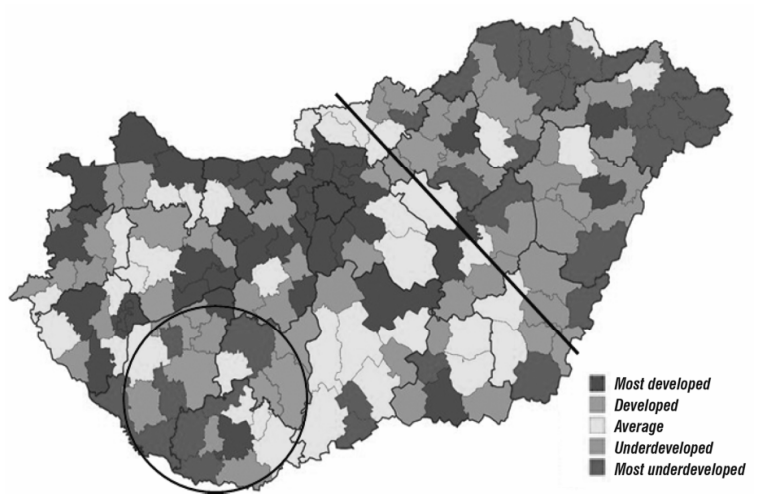

Source: KSH Regional Statistical Yearbook (2008)

A wide range of calculation and procedures have served the determination of the disadvantages of small regions and municipalities for a long time. The best known and most widely used formal procedure takes into account large groups of economic, infrastructural, social and employment data and a wide range of statistical data of their subsystems at the complex index calculation measuring the sub-regions' and municipalities' socio-economic and infrastructural backwardness and/or development. The classification of disadvantaged and the most disadvantaged regions are prepared in this way from year to year based on special parliamentary resolution. At the moment, the government regulation made on the basis of 67/2007. (VI. 28.) National Assembly decision regulates the classification of disadvantaged micro-regions, of which 48 are the most disadvantaged micro-regions, and 47 were classified as disadvantaged, also expressing that the settlement related to the host small region belongs to the same classification. The third category ceased to exist in 2007, which took the most disadvantaged settlements into account separately that did not belong to either one of the most disadvantaged micro regions. In terms of their socio-economic position the difference between sub-regions and their communities is reflected by the superlative form of the word "disadvantaged". The common feature of disadvantaged areas is that their sustainable development, possibly their integration, requires major internal and external development resources (figure 2).

Figure 2: The position of the disadvantaged and the most disadvantaged micro-regions in Hungary (2007)

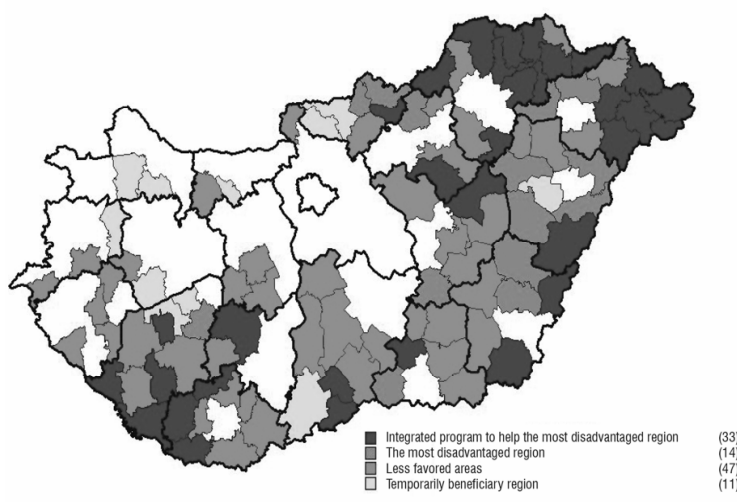

Source: KSH Regional Statistical Yearbook (2008)

The accumulation of disadvantage, also because of the historical and socialist development, appeared equally in the Great Plains including the Tisa River's narrower and wider environment, with all its mutually reinforcing adverse impacts. The post processes of 1989/90 transition modified - rather worsened - the outlined situation, in the period of socialist development, despite all contradictions, industries, bringing significant benefit position, especially heavy industry, and partly agricultural processing industry were built off first, and formed the so called rust zones due to acute unemployment. The occurred processes of deindustrialisation equally affected the earlier advantage enjoying Northern Hungary, Great Plain, along the river Tisza and the SouthTransdanubian areas and settlements. Considering the socio-economic consequences of their fate, the historical past and present therefore can be linked (figure 2).

The process which is very characteristic of the Great Plains and the Tisza region and its environment demonstrates the characteristics of inner and outer peripheral formation best. Although internal and external peripheries can be found throughout the country, typically, in the largest number and most widespread form, they 
occur in the Great Plains, and particularly in the Northern Great Plains, and in North-Eastern Hungary. In addition to what is being said, regarding the formation of periphery, the Great Plains shows perhaps most typically not only the historical antecedents, but the consequences of historical processes and the characteristics of current and after the regime change periphery formation. All this is important to emphasize because in the eastern part of Hungary in the decade following the transition social and regional disparities have not decreased, indeed significantly increased in ownership, educational, cultural, employment, demographic, health, social relations. In the regions struggling with structural and traditional disadvantages significant social, economic and territorial inner differentiation has taken place, and compared to more advanced regions, in small regions and municipalities in various (economic, infrastructural and social) areas a falling behind have occurred, meanwhile problems arose, various new inequalities have again been created, especially in the acute employment crisis.

Regarding the perception of the characteristics of the socio-economic development, the identity in the views between researchers is now quite large, particularly regarding changes in the conditions and nature of social processes, since the well-known historical symptoms of the „Plain Syndrome” affected the changes taking place in the society of the Great Plains most characteristically. The most characteristic manifestations of the Plain phenomenon include colorful diversity; underdevelopment carrying elements of development; the characteristic „emotional connection" and "landscape mentality" developed by the close interaction of the natural landscape and social development; wilderness, frontier nature forming the specific social structure of the Great Plains (which is primarily a social formula, and only secondarily an area development type); the peripheral nature of the Great Plains, in some extensive areas the „periphery of periphery" situation; disharmonic changes in economy and society, specific social development path embodied in the non-compliance of social and economic development: peasant civilization, peasantcivil urban-agriculture development; unique Great Plain settlements and urban development, and at all, many other unique features of the "Great Plain road" (Baranyi, 2002; 2011).

The above described, historically specific „Great Plain Way" of social development, which simultaneously represented relative underdevelopment and development features, has got stuck during the historical, economic, and social changes over the past half-century. Examining the framework, is easy to see that among the old and new factors influencing social processes (for example, the adverse consequences of the historical heritage, inherited traits of the traditional agricultural society, the farm system, commuting, selective migration, strengthening of the periphery situation, etc.) the recent economic crisis has been the most severe. All these both separately and together played a role in the establishment of social specifics and regional differences (Baranyi, 1985) (figure 3).

The transition, the transformation of the Hungarian economy occurs again in an in-depth regional economic climate. The basic characteristic of a regional crisis is the collapse of the eastern part of the country. One of its most obvious signs is that in the counties of eastern Hungary severe and persistent unemployment accompanies the transformation of the economy. Radical ownership, structural and organizational transformation inherent with the change of economic system of 1989/90 did not improve the position of the peripheries of the large regions. The disadvantageous position of the extensive Great Plain agricultural areas, rural areas did not relent, and even the real losers of socio-economic deconcentration process were the settlements along the River Tisza. Compared to the centres built on the Budapest and the socalled industrial axis of the country, regions and settlements belonging to the whole Great Plains, including the Tisza environment remained in a peripheral position, extensive border areas and inside regions trapped in an "island situation" even have become the "the periphery of peripheries" (figure 1-3).

Figure 3: The 33 most disadvantaged micro-regions in Hungary (2009)

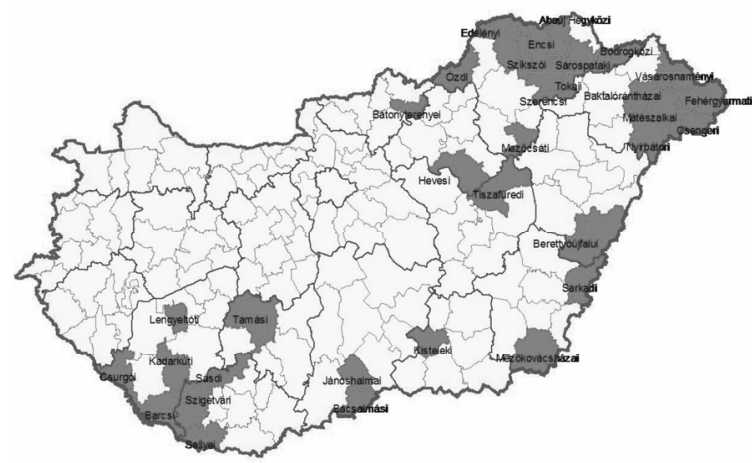

Source: Net 1

It remains an open question how the expected benefits of the country's accession to the EU, in other words subsidies, will contribute to the radical change of the center-periphery relationships, which will be highly needed for the promotion of the Hungarian convergence of peripherals, the effectiveness of cohesion policy, because peripheral regions will hardly or not at all be able to emerge from the long-term crisis on their own. From the perspective of regional development, the earlier prognoses can only be confirmed today that the immediate and wider area of the Tisza region, in particular the economic-social convergence of the settlements, municipalities located in its environment based on only their own resources can hardly be achieved in the near future, the lagging behind of those who cannot develop by their own may continue (Paksy, 1992). May therefore remain the truth of György Enyedi's (2005) general finding which particularly applies to the Great Plains, namely, that the history of the Great Plains is belatedness in a belated country, placed in the semi-periphery of the semi-periphery, considering its level of development the area is still semi-peripheral, somewhere on the periphery of the European Union. 


\section{REFERENCES}

Baranyi B. (1985): A Tiszántúl átalakuló társadalma (1945-1978). A társadalmi átrétegződés fő folyamatai és történeti összefüggései a Tiszántúlon. Akadémiai Kiadó. Budapest. 200.

Baranyi B. (2002): Új folyamatok az Alföld társadalmában. [In: Csatári B.-Timár J. (szerk.) Területfejlesztés, rendszerváltás és az Alföld.] Magyarország az ezredforduló. IV. A területfejlesztési program tudományos megalapozása. MTA Társadalomkutató Központ. Budapest. 29-58.

Baranyi B. (2004): Gondolatok a perifériaképződés történeti előzményeiröl és következményeiröl. Tér és Társadalom. 2: 1-21.

Baranyi B. (2011): Alföld - táj, régió, identitás. [In: Gecsényi L.Izsák L. (szerk.) Magyar Történettudomány az ezredfordulón. Glatz Ferenc 70. születésnapjára.] ELTE Eötvös Kiadó - MTA Társadalomkutató Központ. Budapest. 809-827.
Baranyi B. (2012): Integrált területfejlesztés. (Elméleti jegyzet.). Budapest. 178. in print

Enyedi Gy. (2005): Európa peremén? [In: Nagy E.-Nagy G. (szerk.) Az Európai Unió bővítésének kihívásai - régiók a keleti periférián III.] Alföld Kongresszus. 2003. november 28-29. Békéscsaba. Nagyalföld Alapítvány. Békéscsaba. 7-11.

Net 1: www. nfu.hu

Paksy G. (1992): A Tisza szerepe a térség területi, települése szerkezetének formálódásában. [Baukó Tamás (szerk.)] 101-105.

Sinóros-Szabó B. (szerk.) (2012): Tiszatér-környezet stratégiai fejlesztése. Keleti Háromhatár-Szeglet Kutató-Fejlesztő Központ. Mátészalka.

Tisza stratégia... (2010): [In: Koszorú L. et al. (szerk.) Tisza stratégia megalapozása 2010.] Város-Teampannon Kft. Budapest. 